+Edwards-Groves, C., Grootenboer, P. Hardy, I., \& Rönnerman, K. (2018). Driving change from 'the middle': Middle leading for site based educational development. In Special Issue "Middle Leadership: Practices, policies and paradigms, in School Leadership and Management. https://doi.org/10.1080/13632434.2018.1525700

\title{
Driving change from 'the middle': Middle leading for site based educational development
}

\begin{abstract}
100 words
Educational researchers have invested much in isolating the specific 'drivers' that influence school change and teacher professional development. In this vein, this article draws attention to necessarily situated understandings of practice development through research into the nature of 'middle leading' for site based education development in one primary school district in regional Australia. Drawing on practice theory, the analysis reveals how developing and sustaining change in schools is contingent on middle leaders' insider knowledge, shared responsibility and capacity to sustain and 'drive' teachers' learning. The article argues more situated understandings of middle leading practices are essential for sustainable educational reform.
\end{abstract}

\section{Key words}

Middle leading, practice, practice architectures, professional change, site based education development, teacher leaders

\section{Introduction}

Teachers' daily work is increasingly scrutinised, often in relation to reductive approaches towards teacher accountability and student achievement, such as those associated with professional auditing or standardised testing. At the same time, researchers have invested much in isolating the specific 'drivers' that support (and inhibit) educational development (for teachers and students) and school change (Fullan, 2011). Performative conceptions of accountability and measurement, reductive understandings of 'effect sizes', 'key performance indicators', 'best practice' and decontextualized 'what works' approaches have been promoted as solutions to (perceived) intractable educational problems. However, these approaches often fail to have the best and longer-term effects in schools, and perhaps have been suggested to be examples of the 'wrong' rather than the 'right' drivers for educational change (Fullan, 2011). Often these 'popularised' systemic drivers have proved to be little more than destabilising distractions that divert attention from necessarily situated understandings of practitioners' work and development as it is experienced in practice in schools. In response, this article turns to a more situated, site based understanding of education development.

Drawing upon empirical research into school reform in three primary schools in one school district in regional New South Wales, Australia, this article elaborates a more dynamic conception of what drives education development in schools. Specifically, we examine the practices enacted by a particular group of teachers we describe as middle leaders who lead 
the professional learning of peers at their particular school, a concept described by Kemmis et al. (2014) as site based education development. This concept foregrounds the need for "development of education and educational practices to be appropriately and effectively responsive to the local needs, opportunities and circumstances of students, schools and communities in diverse and different local situations - at each local site" (p. 213). The analysis of practices of teachers occupying middle-level roles in schools reveals how sitebased education practices creates conditions for teacher development and change. Moving away from more dominant scholarship on educational leadership, often focused on the principal, we begin by presenting literature describing middle leading practices, and the role of the middle leader in and for education development in specific primary schools. While middle leading is critical to pedagogical development, it has received relatively little attention (Harris \& Jones, 2017), particularly in primary schools. The study, therefore, contributes to the dearth of research examining middle leadership for professional learning in primary schools. Unique in this article, and as a form of triangulation, data from interviews from middle leaders, principals and teachers provides data not often reported together in the literature.

In this article, we draw upon recent theorising of practice and its constituent conditions that enable and constrain the conduct of practices as these occur in sites. These conditions are described as 'practice architectures' (Kemmis et al., 2014). Since practices do not occur in a vacuum, this position considers how practices are enmeshed and enacted amidst particular kinds of practice architectures (or 'shaping conditions') present at the site of practice at the time of practising. This is a site ontological perspective (Schatzki, 2002) that foregrounds the importance of context, local conditions and circumstances. Thus, a central aim of the research presented here is to locate and describe the distinctive and generative practices (EdwardsGroves \& Rönnerman, 2013) of middle leaders who drive education development in sites. We conclude with a discussion of the implications of such an ontological, practice-based approach for securing sustainable change in schools.

\section{Leading educational development from the middle: a review of literature}

Educational leadership, focused on effective education and school improvement, has long been a focus of research and scholarship (Bass, 1996; Burns, 1978; Fullan, 2011; Lingard et al., 2003). Indeed, when consideration is given to effective education and school development, issues of leadership are inevitably and rightly part of the discussion. Some literature focuses upon variously understood 'heroic' (Amanchukwu et al., 2015) or 'transformational' (Bass, 1996) conceptions of leadership, differing from similarly broad 'transactional' approaches (Burns, 1978). Yukl (1999) argues that various forms of transformational and charismatic leadership tend to have a bias towards 'heroic' leadership. However, an emphasis upon the role of the principal dominates. Arising from concerns about these more 'individualistic' approaches to leadership, there is a significant body of literature that foregrounds various forms of 'distributed leadership'. Spillane (2006) argues distributed leadership shifts the emphasis away from formal leaders (typically principals) to other members of the school community. Significantly, distributed leadership emphasises the relationships between people in leading roles and the 'situated' nature of these relationships. 
Consequently, distributed leadership has the potential to cultivate powerful organisational change (Harris, 2008), along with improved organisational performance and outcomes (Leithwood, Mascall, et al., 2007).

Research examining leadership practices within schools has endeavoured to draw necessary attention to actual change at the level of classrooms, since principals and others in more formal hierarchical school leadership roles (particularly in larger schools), can be at some distance from the classroom since they may not be responsible for directly teaching students. In a study considering principal effects on student outcomes conducted in Australia by Lingard et al. (2003), it was found these 'were small and indirect', and 'heavily mediated and limited' (pp. 51, 148). Arguably, to help address such limitations, the study of leadership has expanded its attention towards the practices of educators in the school who are more directly responsible for building, leading and driving change possibilities among teachers and students in schools. Such figures are sometimes described as persons in more 'middle management' and 'middle leadership' positions.

\section{Understanding middle leading}

Many school principals and systemic administrators have recognised and invested in 'expert teachers' (Collinson \& Cook, 2007) responsible for leading the practice development of their colleagues. This has been considered as a move to secure enhanced results, particularly in relation to more standardised markers of achievement (such as improved literacy and numeracy test results). But, as Fullan (2011) asserts, these are ineffective drivers that 'fundamentally miss the target' (p.5). In part, the bureaucratic policy push towards a 'performative audit culture' (Comber \& Nixon, 2011, p. 168) has increased attention directed to the work of 'middle-managers' (Dinham, 2016; Glover, Gleeson et al., 1998; Gunter, 2001). Subsequently, there is an increasing body of literature that describes the work of these educators who occupy more 'middle level' roles in schools.

Middle leaders are often described as leading or highly accomplished teachers, with a predominant responsibility for classroom teaching (Glover et al., 1998). They have a primarily educative role that builds capacity among others, by facilitating professional development and investing in practices that reach more directly into the classroom (Grootenboer, Rönnerman \& Edwards-Groves 2017). Positioned as a 'buffer and bridge' (Bennett, Woods, Wise \& Newton, 2007, p. 462), middle leaders operate in the middle between the principal and other teaching staff (Grootenboer, Edwards-Groves \& Rönnerman, 2014). They work in spaces that operate up (to the principal) and across (with colleagues), often connecting the school's policy directions and initiatives to the real time pedagogical practices in classrooms. The role and development of middle leaders and their practices was studied by DeNobile (2018) who found that principal support and professional development were noteable influences on success. DeNobile's study (2018) also highlighted how roles ranged across more managerial activities and staff supervisory roles associated with capacitybuilding. According to DeNobile (2018) middle leaders perform these roles through managing relationships, communicating effectively, leading teams, managing time and 
themselves, and importantly to facilitate a culture of relational trust among staff (EdwardsGroves, Grootenboer \& Rönnerman, 2016).

In the Australian context, there is a considerable emphasis upon middle leadership in secondary schools. Gurr and Drysdale (2013) report that middle level leaders' practices are strongly influenced by how their roles are configured in particular sites. While some are expected to serve as leaders who, through leading professional learning, and influencing teaching and student learning, others are unsure about the nature of their roles and have fewer opportunities to exercise their influence. Dinham's (2007) research on secondary school heads of departments' practices revealed how a focus upon students' learning was central to students' success, and their commitment to their effectiveness as teachers, their capacity to build a cohesive team, and the valuing of professional learning, were all key values or practices identified. Middle leading, however, is a contested space. As Bennett et al. (2007) showed, tensions arise with the need to align with the whole-school reform agenda while remaining loyal to their departments, or that they simultaneously cultivate collegial relations even as they were increasingly subject to tighter line-management processes within their own schools' hierarchies. Alternatively, as DeNobile (2018) found, the tendency for some middle leaders to view themselves as curriculum managers, rather than functioning collegially, collaboratively and as co-learners with colleagues was equally problematic.

There is a growing body literature that seeks to connect issues of school leadership with professional learning, often in relation to the cultivation of positive school cultures and effective professional learning communities. Carpenter (2015) reports on research undertaken in secondary schools in the mid-western USA, revealing instances of effective collaborative learning amongst teachers, and how school leaders sought to foster such initiatives. In one of the few studies of middle leading in primary schools, Vanblaere and Devos (2016) employ a multilevel survey analysis in Belgian primary schools to reveal a relationship between instructional leadership and perceived participation in reflective dialogue and deprivatized practice. Harion, Goh and Chua (2015) investigated 'teacher leadership' in their analysis of leading professional learning in three government primary schools in Singapore. Findings highlighted how teacher leading is influential but dependent upon their facilitation skills, subject content knowledge, teaching experience, as well as their capacity for establishing and managing collegiality in professional learning. This latter work is one of few studies dealing explicitly with specific practices associated with middle leadership for teacher learning, and the complexities that surround these concepts.

Counter to a hierarchical conception of the middle manager that conjures up visions of bureaucracy of line management in business (Gunter, 2001), we consider the middle leader within an ecology of education practices. Taking this view orients towards the notion of middleness (Glover et al, 1998) that highlights the 'blurriness' of positionality. Past research has shown how middle leaders are critical for developing educational outcomes for students, because they exercise their leading in and around classrooms, and in and around their teaching peers (Grootenboer, Edwards-Groves \& Rönnerman, 2014; Harris, 2005). It recognises the fundamental relationship between principals, teacher leadership and school improvement (Harris, 2010), but more specifically the relationship between the complex of 
education practices - student learning, teaching, professional learning, and leading (Kemmis et al., 2014). Middle leading, thus, entails a set of intricate ecologically interconnected practices that encompass concurrent i) leading and teaching by ii) managing and facilitating educational development through iii) collaborating and creating communicative spaces (Grootenboer, Ronnerman \& Edwards-Groves, 2017).

\section{Conceptual approach and resources}

The article explores the particular cultural-discursive, material-economic and socio-political conditions that enable and constrain teacher learning in particular school sites, as well as the specific practices that constitute and are constitutive of these conditions.

\section{Site based education development}

Site based education development is a phrase coined by Kemmis et al. (2014) to describe the situatedness of locally enacted leading and learning practices. These practices respond to local exigencies and contingencies in schools and their communities, including specific cultural, material and political resources and influences present at the time. They suggested that,

practices are not performed from predetermined scripts; the way a practice unfolds or happens is always shaped by the conditions that pertain in a particular site at a particular time. The practices that we observe in real life are not abstractions with an ideal form of their own; they are composed in the site where they happen, and they are composed of resources found in or brought to the site: cultural-discursive resources, material-economic resources, and socialpolitical resources. (p. 33)

While educational reform can be initiated at a centralised level (e.g., national, state or district office), it always has to be realised (and enacted) at a local level. Although much is made of educational practices in places distant from classrooms such as government departments or school principal's offices, these only have meaning and relevance because they aspire to relate to the everyday teaching and learning practices that happen in classrooms. It requires the creation of "communicative spaces for practitioners to explore ways to develop and transform their educational practices and the practice architectures that support them" (Kemmis et al., 2014, p. 219). A more site-based ontological position thus requires educational leading that is exercised not just at a distance from the classroom but also, and more importantly, in and around classrooms.

\section{The theory of practice architectures}

To understand middle leading practices, the language, activities and relationships that encompass these practices need to be examined. To do this, we draw upon the theory of practice architectures (Kemmis et al., 2014) that describes how practices are always composed of interdependent

- sayings that exist in language and thought, and shaped by particular culturaldiscursive arrangements;

- doings that exist in activities and actions, and shaped by particular material-economic arrangements, and; 
- relatings that exist in relationships, power, agency and solidarity, and shaped by

particular social-political arrangements (Kemmis et al., 2014).

These arrangements are practice architectures that prefigure, but do not necessarily determine, the enactment of practices that exist in the site. Thus, practices are always mediated practically, discursively, ontologically and temporally by site-based conditions. At the same time, practices themselves reciprocally cultivate and constitute practice architectures, since they create the conditions for other practices that subsequently transpire. Practices are therefore, both mediating and mediated. The theory (represented diagrammatically in Figure 1 below) provides a lens with which to understand the dimensions of language, work and relationships in-situ, revealing what constitutes and mediates the practices of middle leaders responsible for facilitating school-based development.

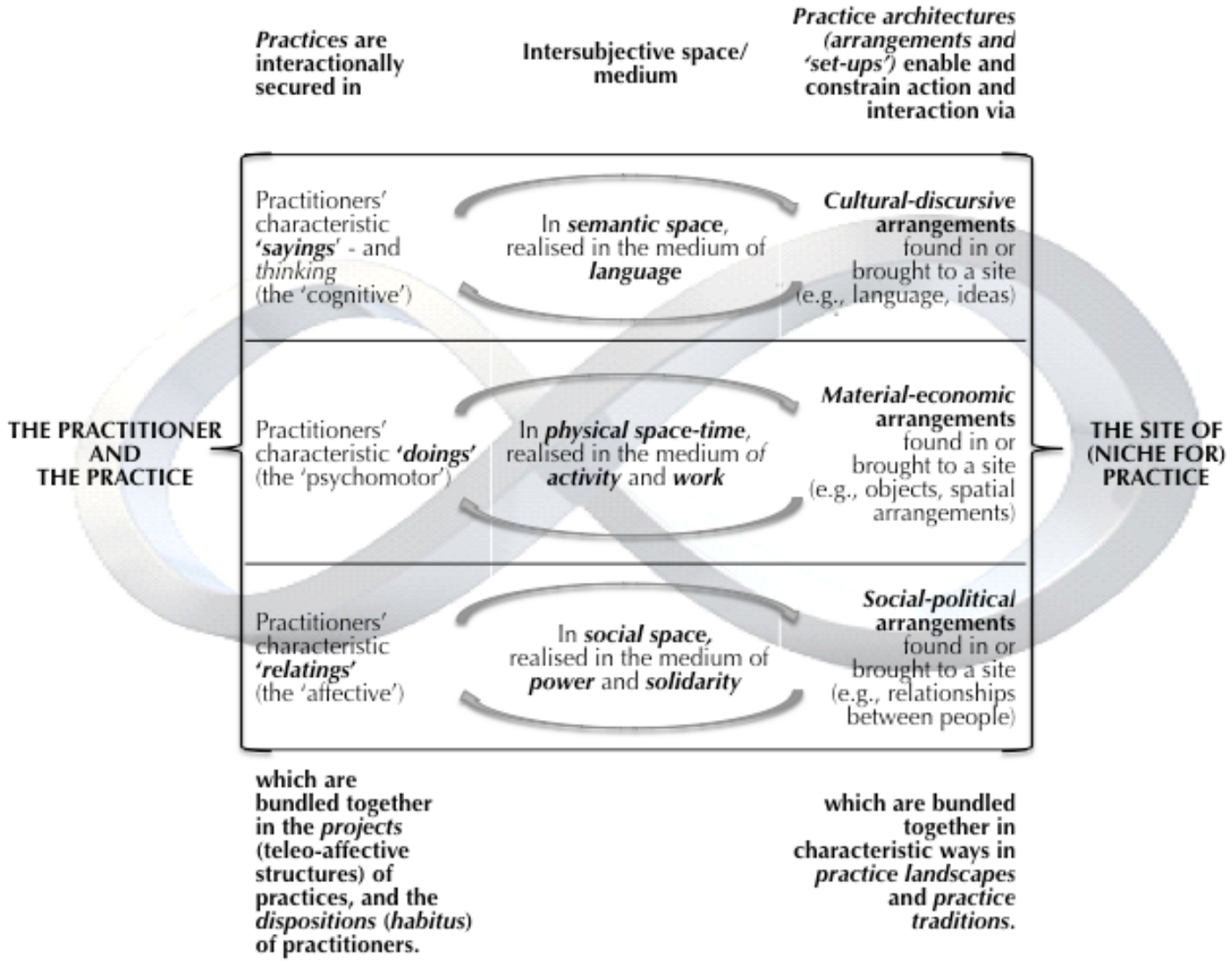

Figure 1: The theory of practice architectures (see Kemmis et al., 2014, p. 38)

The theory of practice architectures provides a useful frame to understand the scope and intricate interconnectedness of education practices as these unfold symbiotically in the sayings, doings and relatings that happen in practices. For example, in appreciating the practices of individual middle leaders (i.e., the left-hand side of the figure), the particular conditions and arrangements that enable and constrain those practices are simultaneously considered (i.e., the right-hand side of the figure). Based on this theoretical position, the study presented in this article aimed to address these research questions: 
1. What is the influence of the middle leader on site based education development in primary schools?

2. How do stakeholders, principals, teachers and middle leaders, account for the development of pedagogical practices in their school?

\section{The study}

To address these questions, we present research from an 18-month qualitative study examining middle leading practices in three primary schools in a rural school district in NSW, Australia. To draw out a comprehensive account of what characterises middle leading practices in these schools, we present a study of middle leaders' practices as they led the professional learning of colleagues in their school primary settings. The single case allows us to capture deeper insights into the nature of middle leading as experienced by the range of educators in sites in more localised and distinctive ways.

The participants: School 1 was located in a small rural town, and comprised 156 students, 9 teachers and 1 middle leader, who was shared with 2 other small schools. The second school, School 2 was located in a large rural town, with 435 students, 36 teachers and 2 middle leaders. School 3 was located in small rural town with 244 students, 20 teachers and 1 middle leader. The schools were purposively selected (Bryman, 2012) from a district that was actively engaged in fostering middle leading practices for school reform concerning improving student literacy results. Teachers in each site were invited to be involved in the observations and interviews, with 15 volunteer teachers from across the three schools (four from School 1, six from School 2, and five from School 3) giving informed consent to participate in focus-groups; middle leaders and their principals consented to participate in the recorded interviews. The research was conducted within the parameters of all relevant university ethics protocols.

The data: Data for this article are drawn from two hour-long semi-structured interviews conducted with three middle leaders (six interviews in total), semi-structured interviews with each school principal (three in total), and six debrief focus group interviews involving a total of 15 teachers. Observations of professional development sessions and classroom teaching were also made, but not drawn on in this article. Focus groups and semi-structured interviews were conducted to develop detailed participant accounts and associated attributions of participant experiences and explanations (Freebody, 2007). The 15 interview recordings were transcribed for analysis.

Data analysis: The project employed a multi-site case study approach (Stake, 1995) to explore the influence of middle leading practices on site based education development within the three individual schools. After an initial independent examination of interview and focus group data, the researchers (independently and then collectively) identified emerging themes that reflected recurring concepts within and across the school sites. Drawing out themes on the basis of identified categories (Stake, 1995) involved various iterations of coding and recoding to establish aggregated categories. Drawing upon a more hybrid approach to analysis involving both induction from the data and deduction through relevant theorising 
(Reichertz, 2014), themes were simultaneously examined to delineate the associated practice architectures that emerged across the corpus. Therefore, reflecting a 'thinking with theory' approach to data analysis, the categorisation was simultaneously informed by the theory of practice architectures (Kemmis et al., 2014).

\section{Results and analysis: Driving change from the middle}

Analysis interview and focus group data with middle leaders, principals and teachers established three interlinked themes describing the role and influence of middle leading in school-based professional development. These will be discussed in turn: i) knowing the site and being responsive as 'insiders' to the site; ii) sharing responsibility and commitment to the site, and; iii) developing and sustaining change in the site. Each section provides some texture to the nature of middle leading practices that happened in the site.

\section{Knowing the site: being insiders to professional and community circumstances}

A central theme across the data concerned the importance of knowing the complex of issues influencing what happens in local schools from an insider's vantage point. According to informants this meant knowing the community where the school is situated - including knowing about teaching, the staff and the student body. In this first excerpt from a focus group interview with four teachers from School 1, Carol raised the matter of being an insider as key to steering successful school development. Carol says of Sally (the middle leader in the school):
It works because she knows our school community, well she lives here; and we are a poor school and a lot of the kids have pretty low vocabulary. She knows us too, so we have in-built relationships ... she was also practising what she was teaching us with her own students. She was actually trying to do it, and she admitted her struggles. Sally has such a sense of humour- very human. And all of those things come together more easily to build us as an amazing collegial team who want to be better. I think just being one of us, an insider to teaching so to speak, helps us just want to get better at this. It's elusive, but I think that's a key.

Carol's comments suggest that being an insider to the site is central for establishing the kind of relational trust (Edwards-Groves et al, 2017) that fosters what "works" at their school. She reinforces how it is the interactions between those in situ that are not only crucial for developing more distributed modes of leadership (Spillane, 2006) but professional learning build from creating communicative spaces receptive to change. For instance, Carol considered knowing the community and student and staff needs provides an "in-built" mechanism for improvement, and so developing the necessary capacity-building characterising effective middle leading (DeNobile, 2018). As she highlighted, having "inbuilt relationships", as Sally did, enables those in the practice to "come together" to "build collegial teams" "more easily." The notion of ease here is important as it gestures towards other approaches to professional development that might be less straightforward, perhaps more ineffectual. Although Carol suggested that pinpointing the key to change is "elusive", she explicitly acknowledged that being "an insider to teaching" and "practising what she was teaching us with her own students" was elemental. This practice, along with the 'doing' of "admitting her struggles" with changing practices for herself, grounds the change in real 
terms in the site. In her interview, Sally (middle leader) aligns with this view, suggesting her place at the school as a teacher is pivotal for facilitating change:

Being in the classroom too, I'm like them. I'm teaching and managing all that comes with that, and I'm struggling with it [the new curriculum] myself in relation to how things really are with my children, where they are on the continuum ... trying to find the balance. I'm not someone who's sitting in an office saying, 'This is what you have to do', with no understanding of all of those day-to-day things that encroach on teaching.

Knowing the conditions that effect what happens, "that encroach on teaching" in the everyday as Sally states, strengthens connections between the realities and processes of change for teachers with the realities of "how really things are" in the site and external pressures or demands (like the new curriculum or the continuum). This is an instance of the importance of 'relatings' that characterise productive relationships necessary for middle leading. For middle leaders like Sally, the connection is made stronger because of a genuine knowledge of the practices of teaching and an admission of her own struggles and vulnerabilities in undertaking and indeed accomplishing change. More anodyne conceptions of 'heroic' (Amanchukwu et al., 2015) or even 'transformational' (Burns, 1978) leadership seem removed from these more intimate, situated, context-responsive practices. In one way, recognising the humanness of the issues (also pointed out by Carol earlier) ties persons, personhood and practices together in sites. It orients to how such admissions come from a deep understanding that can only come from insider knowledge of the site and of the practices that exist there. It is an idea also captured by Grace (the principal of School 2) in this next excerpt as she talks about Brenda's middle leading role in facilitating learning amongst her colleagues:

What is really important I think is that you can read all this stuff to your heart's content, juggle the testing balls and so on, but unless you've actually been through it, actually be in it as a teacher like Brenda, can you be a real driver of change? Or I should say driver of real change? Being a teaching leader helps us connect, and to be honest, what she does has got to make sense here. So, can you really get it if you don't know where you are and who you are dealing with?

The ability to critique external agendas like national testing, the 'wrong' drivers of change (Fullan, 2001), reveals how Grace herself was engaging in the sort of leadership practices necessary to support the work of middle leaders (DeNobile, 2018). She puts it into perspective by asserting that to be a "driver of real change" (Fullan, 2011) begins from a position of knowing the site, "where you are and who you are dealing with". As she indicates, the 'doing' of being in touch from the inside "makes sense here" for others present. Grace's mention of the word "here" orients directly to the school's situation; it is a site ontological view (Schatzki, 2002) that stresses the importance of understanding the situatedness of practices. Therefore, part of middle leading practice requires being a leader of teachers, a 'teacher leader', who knows how to act in situ. This insider view of practices is not an abstraction with an idealised form of its own about practices; rather it orients to the notion that middle leading practices are composed in the site where they happen and as they happen (Kemmis et al., 2014), and from a position that overtly accounts for local contingencies and exigencies present. 
The specific 'doings', 'sayings' and 'relatings' of the middle leaders were also influenced by the professional conditions that existed in each school. Shelly, a middle leader from School 3, reinforces the importance of connectivity between knowing and responding to the particular professional conditions that characterised her school:

What I do with the teachers has to respond to where they are, what they need and their willingness to change... I will lose them if I go in all gung-ho... even though it is a whole school thing, it needs to be individualised ... and take into to account their different learning styles and their own knowledge... some are resistant to change... all these things really do influence the way I go about it.

Such conditions serve as part of the practice architectures that influence what is possible, and Shelly recognises that her doings (activities) and sayings (discourse) have to "account for" and "respond to" the needs of teachers in her school; this is multidimensional and complex. For Shelly, this includes knowing and responding to what the teachers know, can do, need, their willingness to change, their different learning styles and so on; as in other primary schools settings internationally (Harion, Goh \& Chua, 2015), it entails deep knowledge on the part of the middle leader to be successful.

Using the site as a resource and starting point, was also reflected by Maria, a teacher in a focus group interview in School 2, who flagged the importance of connecting to teachers' circumstances:

The most sensible starting point is having the time and place to talk about and connect to our own situations, the fact that many students here have low vocabulary, and really unpicking, what to do to improve their vocabulary learning. That way, you know, we respond more directly and the impact will be greater... It's based around bringing together what we need and know as teachers, and what the students need and know as learners. The critical part was she [Brenda] led us to think about how to tie the curriculum to the kids here ... I think that is the necessary platform to make it actually happen.

Here Maria highlights several interconnected points that she acknowledges to be not only "sensible", but "critical" in making an "impact" in the school - in effecting powerful organizational change (Harris, 2008). In fact, she suggested that responsivity is a "necessary platform" for actually making change happen in her situation. Knowing the teachers and their professional needs, and the students and their learning needs (more limited vocabulary as indicated in this case), are important initial steps for ensuring that people were not just (as Maria continued) "talking in a vacuum or going off to one-off PD days and dipping in and dipping out of bits and pieces". Maria's colleague Rodney explained further:

Making it happen means taking on board what others think, considering what are some alternative pathways. What other professional reading do we need? With Brenda, it was always well 'let's check'. Based on what we already know between us, we can see whether this fits with that, thinking how else you could do it? So there was so much having time to test our assumptions and trial new ways, being on that journey with us was the whole thing.

"Making it happen", according to Rodney, and the potentially improved student outcomes arising from such distributed leadership (Leithwood et al., 2007), meant participating in 
practices involving checking, testing assumptions, reaching for further reading, considering alternatives and practising, and doing this collaboratively. Brenda, middle leader in School 2, too acknowledged what matters in school based education development is responding to the site and the practices, persons and circumstances that exist there:

What we really do is for kids here at our school; that plays a big part actually. That's what really matters. ... I don't think it is a single variable that takes you forward; but knowing the issues in our community helps the PD hit the mark because you can respond to what we need to do for the kids here.

Critically, such work is student-centred (Dinham, 2007), and for 'expert teachers' (Collinson $\&$ Cook, 2007) such as Brenda, knowing the specific circumstances of her students and the community in which the students were drawn enabled a critical site-based kind of responsivity.

\section{Sharing responsibility and commitment to the site}

Participants in this study recognized the need to share the responsibility for learning and change. As Brenda (middle leader School 2) stated, "I think it works because it is not just one person here or there; we are all responsible." Positioning herself as a learner with her colleagues and sharing in the responsibility for it emerged as a central feature of her facilitation:

I realised that I was learning from the group too; so in my facilitation, I've noticed that I'm actually quite explicit all the time about what are we learning from each other because I hadn't realised [initially] that it was actually the people around me who were teaching me as well!... Their commitment helps to keep us all accountable to each other. So, in one way, together we keep it moving - the interest up and the focus going.

Her practice of explicitly drawing attention to "what are we learning from each other" highlights the value she placed on sharing responsibility for learning in the site.

Deprivatisation of practice through such sharing also reveals evidence of instructional leadership at play (Vanblaere \& Devos, 2016). The site as a collaborative space was a resource for professional learning. Brenda's point that "their commitment helps to keep us all accountable to each other" explicitly raises the matter of recognition and how a shared commitment is pivotal for developing practices there. Such a position is a far removed from more individualistic, 'heroic' conceptions of leadership prevalent within the leadership literature (Amanchukwu et al., 2015). The notion of mutual accountability directly orients to the importance of professional learning being understood as a collective, shared endeavour and enables teachers "together" to "keep it moving", and to keep "the interest up and the focus going". This form of collegiality is central for establishing the 'right' drivers of educational reform (Fullan, 2011).

Sally (middle leader in School 1) extended this idea by suggesting that professional recognition and shared responsibility are also connected to the development of commitment and growth: 
We need to work in such a way that recognises everyone's professional knowledge and that enables the commitment from us all to grow; it's critical for building the sense of collegial learning.

Even as collegial learning could be challenging (Goh et al., 2015), such learning was recognized as 'enabling'. Jed, teacher from Sally's school, framed Sally's commitment as a privilege:

I think we were really privileged to have Sally and her way of doing things and because she's driving it for the sake of the kids, bottom line. Also it engenders a new energy or a courage that we can do it for ourselves ... I think because knowing that someone, one of us, is in it for the long haul helps with driving and steadying the professional development at the school...

In many ways, these attributes are both displays of commitment to, and evidence of success of, the middle leader. His use of the terms "driving" and "steadying" not only imply Sally's role in managing, guiding and facilitating, but her stance on professional development as being about learning over time.

\section{Developing and sustaining change in the site}

Improving and developing practices is a core purpose of professional development and the sustainability of professional development initiatives in practical terms is important. For Henry (principal School 1), having access to Sally as someone to drive professional development in a longer-term way was generative of development of the site in sustainable ways:

It's a real long-term investment in her and in us and improving the learning for kids. I think there is an indifference, even apathy, around just turning up to one-off PD days to get the grab bag of good ideas. These, usually get dropped pretty soon and I think really are a waste of time and money. So having Sally here in the role keeps learning going, keeps us honest.

According to Henry, Sally's ongoing role is a "real long-term investment" in the school, one that appeared to affect practices in productive ways. Reflecting her principal's necessary support for sustaining middle leadership roles (DeNobile, 2018), Sally herself said, "I think that's what we're talking about now - driving change for long term gains of students into the future". There appeared to be a real synergy between collegiality (Harion et al., 2015), teacher leadership and school improvement (Harris, 2008). Securing student gains in the future, implied that practice development required both sustainable approaches (longer term PD) and sustainable outcomes (into the future).

Getting traction for longer term and sustained impact was also a feature of middle leading recognised by Bev (teacher from School 3) in relation to Shelly's practices:

I think how she facilitates - how that's done - fosters very much the approach to PD we need to make a long-term difference. Because I've engaged in... very hierarchical top-down sessions - prescriptive stuff like, 'this is how to do it', and we take it up in a very didactic way that doesn't end up necessarily making it real or lasting. You know we will go on with our job, but drop out mentally quite quickly, because it hasn't engendered a real and deep sense of what it 
means for us. Even though it might be the mandatory stuff, Shelly connects it to us, we can see how it relates to the kids in this disadvantaged community. Then it seems to gain traction for developing in more authentic ways, and that seem to last.

Here, the importance of connecting with students' learning was evident, and how those in middle leadership positions facilitate teacher learning for student learning. Yet, these comments reflect little of the uncertainty sometimes evident amongst some middle leaders (e.g. Gurr \& Drysdale, 2013) about the ends to which their roles should be oriented. This was similarly reflected in the way Helen (principal School 3) expressed her support for Shelly:

Shelly keeps us on course over the course of the teacher-learning journey ... without her being here where it all happens every day, I think the whole thing would go pear-shaped, the initiative would not only lose momentum, but the teachers would lose interest, maybe not stay the distance... actually her drive, drives us.

Sayings such as "journey", "keeping on course", "staying the distance" and "drive", highlighted in Helen's comment, draw attention to the recognition that professional learning is always in a state of motion. Essentially, these conditions generated by successful middle leading create practice architectures (or influences) that are considered likely to foster sustained professional learning. These are the sorts of middle leading practices amongst teachers with additional leadership and administrative responsibilities (Glover et al., 1998) that facilitate and foster change in sites over the longer term.

This is not to say that facilitating change over the longer term is seamless; leading from the middle can be challenging (Carpenter, 2015; Harion et al., 2015). Sally (middle leader School 1) captures the complexities and tensions of middle leading in relation to broader practice architectures when such conditions are more challenging:

Sometimes it's sticky, so being in that position needs nimbleness really, and flexibility in thinking sometimes, both being their peer and their leader at the same time can be hard. Sometimes it is messy, and sometimes it is I hate to say this, even a bit chaotic especially when people resist the process, so that means knowing them and what works for them, this makes it easier to navigate competing agendas and personalities, you know to steer the national agenda, NAPLAN and ACARA, into being something of value and worth for each teacher and ultimately their students.

Even as these leaders are able to develop and sustain productive change, they are also doing this in the context of a broader policy and political conditions that can make this work challenging.

\section{Discussion and conclusion: Middle leading for site based educational development}

Drawing on data from three primary schools in one district in Australia, this article has sought to identify what drives site based education development in primary schools, adding to the limited literature examining middle leading in this sector. Teachers, principals and middle leaders' accounts show changing and sustaining practice development in schools requires attending to conditions within actual sites. Findings indicate how these conditions form 'right 
drivers' that include investing in middle leaders: have deep knowledge of their circumstances and are able to respond as 'insiders'; share responsibility and commitment for the work that needs to occur in the school; and, develop sustainable change practices that bring teachers along with them over time.

Data demonstrate ways middle leaders, as site-based facilitators of change, operate in the midst of different kinds of cultural-discursive (linguistic), material-economic (resources and activities) and social-political (relationships) demands, sometimes with competing agendas. Thus, knowledge of site-based circumstances, together with a drive and commitment to advancing the site, form necessary conditions for middle leaders to be successful (DeNobile, 2018). These dimensions promoted collegial learning pivotal for teacher learning for student learning. Results therefore extend how distributed leadership (Spillane, 2006) can be understood as an ecologically-connected practice where responsibilities for site based education development is distributed to middle leaders and among teachers in sites of change.

For the participants in this study, enacting practices guided by the principles of collegial respect and engagement appear to form the essence of their everyday development work. However, leading site based education development is not a straightforward matter; it requires navigating the complexities of both conditions internal and external to school sites, as they unfold in real time practices. As the analysis of practices in each of the schools reveals, to varying degrees, practices in sites both mediate (or influence) and are mediated (or are influenced) by the presence and impact of such conditions. These mediating conditions practice architectures - create conditions of possibility and of contestation. Thus for some middle leaders, 'doing' change support was "messy" and sometimes "chaotic"; this included under circumstances of resistance to change amongst teachers (internal conditions), and in relation to broader national policy expectations (external conditions). Being responsive to such conditions required a particular kind of "nimbleness" and "flexibility" - of knowing what to say ('sayings'); this comes with deep knowledge and understanding of the site. This is also complicated for middle leaders by "being their peer and their leader"; a consequence of middle leaders' concurrent teaching, leading and administrating roles (Glover et al., 1998). These 'relatings' are potentially both the biggest strength and the biggest challenge for middle leaders. While productive collegial learning does not always occur (Harion et al., 2015), the success of middle leading, is enabled by their capacity to navigate and mediate this multifaceted relational space. Thus sayings, doings and relatings do not only reflect the circumstances in which they unfold, they also constitute mechanisms for changing such conditions, and bringing about more productive conditions.

Findings show that middle leading practices create conditions that drive the change endeavour forward. By examining the work of specific middle leaders responsible for successfully leading professional learning in their school sites, the nuanced particularities that characterise more productive site-based conditions essential for establishing reformed policy and practice are revealed. Consequently, middle leading for site based education development has the potential to reconstruct existing understandings of what it means to apprehend and accommodate local needs and conditions that, at the same time, respond to national, district and other school-based policy imperatives and initiatives. As the research presented here 
highlights, middle leaders are able to reframe abstract initiatives and policies and articulate them in relation to locally realised practices in real terms. Findings show that middle leaders serve a unique navigational role that bridge and (although less so) buffer (Bennett et al., 2007) practices between, within and across these spaces.

Finally, at a time in educational history where there is an escalating tension between meeting prescribed policy demands and the lived realities of teachers constrained by policy, accountability and performativity, there is a need for further research presenting the sitebased practices that sustain teacher change. This provides scope for choosing the right drivers, to hit the target, as Fullan (2011) avows; but this requires deeper understanding of the site-based work and learning of teachers in schools - all of whom are ultimately responsible for change initiatives in schools. Further explicating the specific practices of individual school sites will enable understandings about leading professional learning to be reshaped from dominant (and often problematic) cultural-discursive, material-economic and sociopolitical arrangements that influence teachers' work and learning. Policies describing professional learning need a greater focus on resourcing and attending to the influential role of middle leaders whose practices are pivotal for sustainable change, learning and development.

\section{References}

Amanchukwu, RN., Jones Stanley, G. \& Ololube, NP. (2015). A Review of Leadership Theories, Principles and Styles and Their Relevance to Educational Management. Management, 5(1): 6-14. DOI: 10.5923/j.mm.20150501.02

Bass, B. M. (1996). A new paradigm of leadership: An inquiry into transformational leadership. Alexandria, VA: U. S. Army Research Institute for the Behavioural and Social Sciences.

Bennett, N., Woods, P., Wise, C., \& Newton, W. (2007). Understandings of middle leadership in secondary schools: a review of empirical research. School Leadership and Management, 27(5), 453-470.

Burns, J.M. (1978). Leadership. New York. Harper \& Row.

Carpenter, D. (2015). School culture and leadership of professional learning communities. International Journal of Educational Management, 29:5, 682-694.

Collinson, V., \& Cook, T. F. (2007). Organizational learning: Improving learning, teaching, and leading in school systems. California: Sage.

Comber, B., \& Nixon, H. (2011). Critical reading comprehension in an era of accountability. Australian Education Researcher, 38, 167-179.

Dinham, S. (2007). The Secondary Head of Department and the Achievement of Exceptional Student Outcomes. Journal of Educational Administration, 45(1), 62-79.

Dinham, S. (2016). Leading Learning and Teaching. Camberwell: ACER Press.

Edwards-Groves, C., Grootenboer, P., \& Rönnerman, K. (2016). "Facilitating a culture of relational trust in school-based action research: recognising the role of middle leaders". In Special Issue: Partnerships and Recognition, Educational Action Research. 24(3), 369-386, DOI:10.1080/09650792.2015.1131175

Edwards-Groves, C., \& Rönnerman, K. (2013). Generating leading practices through professional learning. Professional Development in Education, 39(1), 122-140.

Freebody, P. (2007). Qualitative Research in Education: Interaction and Practice. London: SAGE Publications Ltd. 
Fullan, M. (2011). Choosing the wrong drivers for whole system reform. East Melbourne: Centre for Strategic Education.

Glover, D., Gleeson, D., Gough, G. \& Johnson, M. (1998). The meaning of management: the development needs of middle managers in secondary schools, Educational Management and Administration, 26(3), 279-92.

Grootenboer, P., Edwards-Groves, C. \& Rönnerman, K. (2014) Leading practice development: voices from the middle, Professional Development in Education, 1-19. DOI: $10.1080 / 19415257.2014 .924985$

Grootenboer, P., Rönnerman K. \& Edwards-Groves, C. (2017). Leading from the middle: A praxisoriented approach. In P. Grootenboer, C. Edwards-Groves, \& S. Choy. (Eds), Practice Theory Perspectives on Pedagogy and Education: Praxis, diversity and contestation, p. 243-264 Singapore: Springer.

Gurr, D., \& Drysdale, L. (2013). Middle-level secondary school leaders: Potential, constraints and implications for leadership preparation and development. Journal of Educational Administration, 51(1), 55-71.

Gunter, H. (2001). Leaders and leadership in education. California: Sage Publications Inc.

Hairon, S., Goh, J., \& Chua, C. (2015). Teacher leadership enactment in professional learning community contexts: Towards a better understanding of the phenomenon. School Leadership \& Management, 35(2), 163-182.

Harris, A. (2008) Distributed leadership in schools: Developing the leaders of tomorrow. London: Routledge.

Harris, A. (2010). Effective Leadership in Schools Facing Challenging Contexts. School Leadership and Management, 22(1), 15-26, DOI: 10.1080/13632430220143024a

Harris, A. (2010). Building the Capacity for School Improvement. School Leadership and Management, 21(3), 261-270, DOI: 10.1080/13632430120074419

Harris, A., \& Jones, M. (2017). Middle leaders matter: reflections, recognition, and renaissance. School Leadership \& Management, 37(3), 213-216.

Kemmis, S., Wilkinson, J., Edwards-Groves, C., Hardy, I., Grootenboer, P. \& Bristol, L. (2014). Changing Practices, Changing Education. Singapore: Springer.

Leithwood, K., Mascall, B., Strauss, T., Sacks, R., Memon, N. \& Yashkina, A. (2007) Distributing leadership to make schools smarter. Toronto: University of Toronto, OISE.

Lingard, B., Hayes, D., Mills, M., \& Christie, P. (2003). Leading learning: Making hope practical in schools. Maidenhead: Open University Press.

Reichertz, J. (2013). Induction, deduction, abduction. In U. Fleck (Ed.), The Sage handbook of qualitative data analysis. London: Sage.

Schatzki, T. (2002). The site of the social: A philosophical account of the constitution of social life and change. University Park, TX: University of Pennsylvania Press.

Spillane, J. (2006). Distributed leadership. San Francisco, USA: John Wiley \& Sons, Inc

Stake, R. E. (1995). The art of case study research. Thousand Oaks, CA: Sage.

Vanblaere, B., \& Devos, G. (2016). Relating school leadership to perceived professional learning community characteristics: A multilevel analysis. Teaching and Teacher Education, 57, 26-38.

Yukl, G. (1999). An evaluation of conceptual weaknesses in transformational and charismatic leadership theories. Leadership Quarterly, 10(2), 285-305. 